\title{
Increased dimeric IgA producing B cells in the bone marrow in IgA nephropathy determined by in situ hybridisation for $\mathrm{J}$ chain $\mathrm{mRNA}$
}

\author{
S J Harper, A C Allen, J H Pringle, J Feehally
}

\begin{abstract}
Aim-To investigate the possible role of the systemic IgA immune system in the pathogenesis of IgA nephropathy Methods-J chain mRNA expression in the IgA cells of the bone marrow was studied. Bone marrow trephine biopsy specimens from seven patients with IgA nephropathy and seven matched controls were examined by (1) non-isotopic in situ hybridisation (ISH) and (2) combined immunofluorescence and non-isotopic ISH to identify the plasma cell type. Serum polymeric IgA was also determined using standard high pressure liquid chromatography and sandwich enzyme linked immunosorbent assay.

Results-Non-isotopic ISH revealed a similar number of $J$ chain $m R N A$ positive cells/unit length in biopsy specimens from patients $(16 \cdot 5 \pm 2 \cdot 7$ cells $/ \mathrm{mm})$ and controls $(17 \cdot 7 \pm 2 \cdot 4$ cells $/ \mathrm{mm})$. Combined immunofluorescence and ISH revealed a greater proportion of $\mathrm{J}$ chain $\mathbf{m R N A}$ positive $\operatorname{IgA}$ cells in patients $(7 \cdot 6 \pm 1 \cdot 45 \%)$ compared with controls $(3 \pm 0 \cdot 8 \%)$. Serum polymeric IgA was similar in both patients $(91 \pm 22 \mathrm{mg} / \mathrm{l})$ and controls $(77 \pm 24 \mathrm{mg} / \mathrm{l})$. Conclusion-These data suggest that excess production of dimeric IgA occurs in the bone marrow in IgA nephropathy. (f Clin Pathol 1996;49:38-42)
\end{abstract}

Keywords: IgA nephropathy, J chain, bonę marrow.

IgA nephropathy is a common form of glomerulonephritis characterised by the mesangial deposition of IgA1..$^{1-3}$ The molecular nature of the deposited IgAl remains contentious but there is good evidence to support the view that a significant proportion of it is dimeric (J chain positive). ${ }^{4-6}$ Mesangial deposition of dimeric IgA is thought to occur based on the large body of evidence detailing abnormal polymeric IgA biology in IgA nephropathy. ${ }^{7}$

$\operatorname{IgA}$ is the immunoglobulin of mucosal defence. The elevated concentrations of serum polymeric $\operatorname{IgA}^{8}$ and the clinical association of mucosal infection and macroscopic haematuria in IgA nephropathy led to the view that mesangial IgA originated in the mucosal IgA system, and that the deposited immunoglobulin resulted from an exaggerated IgA response, either innate to the mucosal system or secondary to environmental influences. ${ }^{9-11}$

Two tissues from the mucosal immune system have been available for study in IgA ne- phropathy-tonsils and intestinal mucosa. The intestinal mucosa contains a smaller proportion of IgA plasma cells in IgA nephropathy compared with normal mucosa, ${ }^{1213}$ and our previous work on duodenal IgA plasma cell $\mathrm{J}$ chain mRNA expression has suggested a shift away from dimeric IgA production at this site. ${ }^{13}$ These data suggest that the site of hyperresponsive IgA biology in IgA nephropathy is unlikely to be the intestinal lamina propria. In contrast, increased numbers of IgA cells have been identified in tonsils ${ }^{14-17}$ and increased $\mathrm{J}$ chain expression has been reported in tonsillar IgA cells. ${ }^{14-16}$ Although these reports were based on potentially non-specific antibody techniques, we have recently confirmed this finding using in situ hybridisation for J chain mRNA (unpublished data). There is therefore good evidence for a shift towards dimeric IgA production in the tonsils in IgA nephropathy. However, it is difficult to accept that the tonsils are the only site of deranged dimeric IgA function in IgA nephropathy, as although tonsillectomy may reduce the frequency of macroscopic haematuria (and also of mucosal infection), the procedure is not curative.

Furthermore, IgA nephropathy does occur in patients who have had a tonsillectomy as children. An alternative view proposed by van den Wall Bake et $a l^{18}$ is that mesangial IgA derives from the systemic (bone marrow) IgA system. This is supported by elevated IgA plasma cell counts in bone marrow aspirates from patients with IgA nephropathy. We have recently confirmed this finding in bone marrow trephine biopsy specimens from patients and matched controls. ${ }^{19}$ Although bone marrow IgA cell $\mathrm{J}$ chain expression in IgA nephropathy has been studied, ${ }^{20}$ two colour immunofluorescence techniques were used, using a J chain antibody which others have found to be non-specific, demonstrating a tendency to bind to immunoglobulin light chains (Dr M Kerr, University of Dundee, Scotland, unpublished observations).

Here, we describe an in situ hybridisation study of J chain mRNA expression within the bone marrow IgA plasma cells of patients with IgA nephropathy to address whether the bone marrow is an additional source of excess dimeric IgA production in IgA nephropathy. The concentrations of polymeric IgA within the serum of patients and controls were also determined to assess any potential correlation between serum concentrations and marrow cell profile. 


\section{Methods}

Bone marrow trephine biopsy specimens were obtained from seven patients with confirmed IgA nephropathy (six men and one woman, mean age 45 years, range $35-55$ years). None of the patients had macroscopic haematuria at the time of biopsy, six had microscopic haematuria and two had proteinuria. All patients had normal serum creatinine concentrations.

Control samples for bone marrow studies were derived from age and sex matched volunteers (mean age 45.9 years, range 34-59 years), undergoing minor surgery under general anaesthetic.

Collection of bone marrow biopsy specimens from a small number of controls and patients was approved by the Leicester Health Authority Ethical Committee. Sample collection was from willing volunteers who gave informed consent. These samples were identical with those studied previously in that biopsy specimens from the patients had increased numbers of IgA and IgA1 cells. ${ }^{19}$ Biopsy was performed under local anaesthetic ( $2 \%$ lignocaine to skin and periosteum). Bone marrow samples were taken from the posterior superior iliac spine. After collection, the trephine specimens were immersed in $10 \%$ formol saline for 48 hours. Following fixation, all specimens were decalcified (EDTA, pH 7·0, 48 hours), processed and embedded in paraffin wax as for normal histology. Processed samples were then coded. A blood sample was taken at the time of biopsy and the serum stored.

\section{PROBE AND PROBE LABELLING}

Deoxyoligonucleotides (unlabelled sequences were kindly donated by Pathway Services Ltd, Leicester, UK) complementary to $\mathrm{J}$ chain mRNA $^{21}$ were $3^{\prime}$ end labelled with the nucleotide analogue digoxigenin-11-dUTP using a labelling kit (Boehringer Mannheim, Mannheim, Germany). The labelling reaction was performed at $37^{\circ} \mathrm{C}$ for two hours in $100 \mu \mathrm{l}$ volumes. The labelling reaction mixture was as follows: $200 \mathrm{ng}$ probe cocktail; $10 \mu \mathrm{l} 10 \mathrm{mM}$ $\mathrm{MnCl}_{2} ; 2 \cdot 3 \mu \mathrm{l} 1 \mathrm{mM}$ digoxigenin-11-dUTP; $20 \mu \mathrm{l} 5 \times$ buffer; and $1 \mu \mathrm{l}$ terminal deoxynucleotidyl transferase. Labelled probe was then purified through Sephadex G50 spun columns and labelling confirmed by test filters. All deoxyoligonucleotides were 30 bases long; this length has been established as a practical compromise among hybrid stability, hybrid specificity, cost of synthesis and purification, and tissue penetration efficiency. ${ }^{22}$

\section{NON-ISOTOPIC ISH}

The protocol for non-isotopic ISH on decalcified tissue was adapted from techniques we have previous reported for use with paraffin wax embedded, non-decalcified specimens. ${ }^{22-25}$ RNase free reagents and glassware (diethylpyrocarbonate (DEPC) treated; Sigma, Poole, Dorset, UK) were used throughout. Slides were dewaxed with fresh xylene $(2 \times 3$ minutes) and rehydrated through industrial methylated spirit (IMS) $99 \%$ ( $2 \times 3$ minutes), IMS $95 \%(2 \times 3$ minutes $)$. Pretreatments in- cluded protein digestion with proteinase $\mathrm{K}$ $(2-10 \mu \mathrm{g} / \mathrm{ml})$. Samples were post-fixed with $0.4 \%$ paraformaldehyde in $1 \times$ phosphate buffered saline (PBS)/DEPC for 10 minutes, and then acetylated with $0.25 \%$ acetic anhydride. Slides were then washed in DEPC water and returned to $1 \times \mathrm{PBS} / \mathrm{DEPC}$. Slides were hybridised overnight at $37^{\circ} \mathrm{C}$ after a 15 minute "hot-start" at $90^{\circ} \mathrm{C}$ (to destroy endogenous alkaline phosphatase). Hybridisation solution contained $20 \mathrm{ng} / \mathrm{ml}$ probe, $600 \mathrm{mM}$ $\mathrm{NaCl}, 50 \mathrm{mM}$ Tris ( $\mathrm{pH} 7.5), 0.2 \%$ bovine serum albumin, $1 \%$ sodium dodecylsulphate (SDS), $1 \%$ polyvinylpyrrolidone $(40 \mathrm{kDa}), 1 \%$ Ficoll (400 kDa), $0 \cdot 1 \%$ sodium pyrophosphate, 5 mM EDTA, $10 \%$ dextran sulphate, and $30 \%$ formamide.

Posthybridisation washes were as follows: $2 \times$ standard saline citrate solution (SSC; $150 \mathrm{mM} \mathrm{NaCl}, 15 \mathrm{mM}$ trisodium citrate, $\mathrm{pH} 7 \cdot 0.) / 30 \%$ formamide $(2 \times 10$ minutes $)$; $2 \times$ SSC at room temperature $(2 \times 10$ minutes $)$; and 15 minutes in neat sheep serum. Slides were incubated with alkaline phosphatase labelled sheep polyclonal digoxigenin antibody (Boehringer Mannheim) diluted 1 in 600 in sheep serum for 30 minutes. Specimens were then washed in blocking solution, triethanolamine buffered saline, $0 \cdot 1 \%$ Triton-X$100,3 \%$ bovine serum albumin $(2 \times 5$ minutes), immersed in buffer $3(0.1 \mathrm{M}$ Tris $/ \mathrm{HCl}$ $(\mathrm{pH} 9.5), 0 \cdot 1 \mathrm{M} \mathrm{NaCl}, 0.05 \mathrm{M} \mathrm{MgCl})_{2}(1 \times 10$ minutes), and in substrate solution overnight (44 $\mu \mathrm{l}$ nitroblue tetrazolium (NBT) (Sigma, $75 \mathrm{mg} / \mathrm{ml}$ in $70 \%$ dimethylformamide), $33 \mu \mathrm{l}$ 5-bromo-4-chloro-3-indolyl phosphate (BCIP) (Sigma, $50 \mathrm{mg} / \mathrm{ml}$ in dimethylformamide) in $10 \mathrm{ml}$ buffer 3). Finally, sections were washed in running tap water for 10 minutes, counterstained with Mayer's haematoxylin and mounted in aqueous mounting medium.

COMBINED IMMUNOFLUORESCENCE AND NON-ISOTOPIC ISH

The protocol for combined immunofluorescence and non-isotopic ISH was adapted from that reported previously for use on nondecalcified paraffin wax embedded tissue ${ }^{23}$ and was identical with the non-isotopic technique described above up to the detection step. A fluorescein isothiocyanate (FITC) labelled polyclonal rabbit antihuman $\operatorname{IgA}$ antibody (Dako, High Wycombe, UK) was used (diluted 1 in 20) in conjunction with the antidigoxigenin antibody. Specimens were then incubated with a secondary antirabbit polyclonal anti-FITC (Dako) (diluted 1 in 50 in blocking solution) for 30 minutes. Alkaline phosphatase development was then performed. Slides were finally incubated with an FITC labelled polyclonal swine antirabbit antibody (Dako) diluted 1 in 25 with blocking solution. After final washing, uncounterstained slides were mounted in aqueous mounting medium.

IgA plasma cells were then visualised under ultraviolet light (490 $\mathrm{nm}$, green). Coexpression of J chain mRNA could then be determined by alteration to bright field illumination under which J chain mRNA positive cells could be observed (blue/black). 


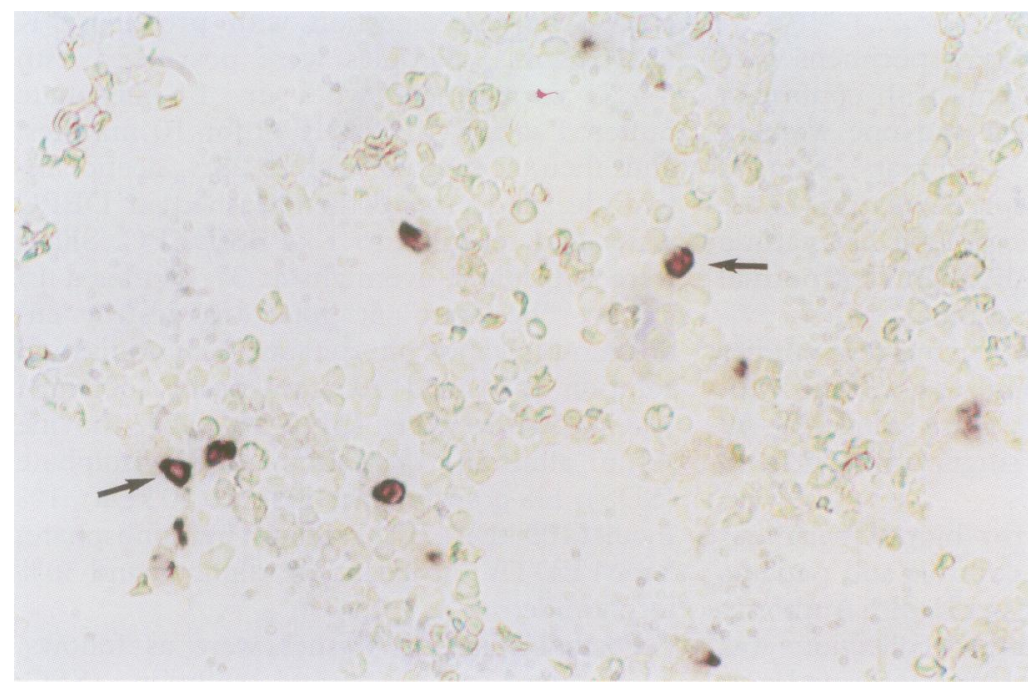

Figure 1 Non-isotopic ISH for $\mathcal{f}$ chain $m R N A$ in a bone marrow trephine biopsy specimen. Visualised using NBT/BCIP (arrows), no counterstain $(\times 400)$.

CONTROLS AND EXPERIMENTAL DESIGN

Specificity of the J chain mRNA signal was confirmed by the use of appropriate negative controls on each section as previously listed. These were omission of probe, omission of digoxigenin antibody, RNase $\mathrm{Al}$ pretreatment controls, random oligonucleotide cocktail similarly labelled (unlabelled sequences kindly donated by Pathway Services Ltd), in addition to a non-homologous oligonucleotide cocktail with the same $\mathrm{G}-\mathrm{C}$ content as the J chain probe. ${ }^{22-25}$

\section{SERUM POLYMERIC IgA}

Serum IgA was measured by radial immunodiffusion as previously reported. ${ }^{19}$ Percentage monomeric and polymeric IgA concentrations in serum samples were estimated. Serum samples were passed through a Superose 6 gel filtration column on a high pressure liquid chromatography system using phosphate buffer, and fractions containing polymeric and monomeric IgA were collected. This procedure was calibrated using commercially purified IgA myeloma proteins (The Binding Site, Birmingham, UK). IgA concentrations in the fractions were measured by sandwich enzyme linked immunosorbent assay as described previously. ${ }^{26}$

\section{MICROSCOPY}

Ultraviolet microscopy was performed using a Nikon Optiphot microscope. After initial study with non-isotopic ISH alone all J chain mRNA positive cells within each biopsy specimen were counted. The length of each biopsy specimen was then measured directly using an eyepiece graticule and low magnification. After simultaneous non-isotopic ISH and immunofluorescence each IgA cell within the specimen was examined in turn in a systematic manner under ultraviolet light $(490 \mathrm{~nm})$ with the aid of a grid-graticule. Expression of $\mathrm{J}$ chain mRNA was then determined by viewing the cell under bright field illumination. Cells were counted by a single observer on coded specimens, thus blinding the observer to the source of each specimen.

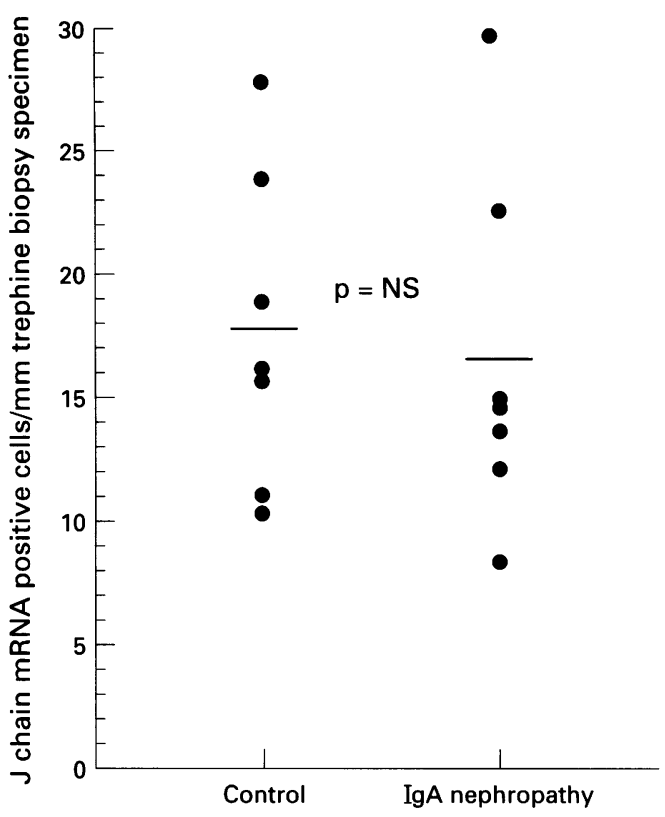

Figure 2 Scatter plot of numbers of $\mathcal{f}$ chain $m R N A$ positive cells per unit length in bone marrow trephine biopsy specimens from seven patients with confirmed IgA nephropathy and seven matched controls. $-=$ mean.

\section{STATISTICS}

Data were analysed using the unpaired $t$ test and Wilcoxon/Mann-Whitney $U$ analysis. Unless stated, figures and results are expressed as mean \pm standard error of mean. Clearly, it should be remembered that the small sample size means that there is a low statistical power to detect a difference between the groups.

\section{Results}

\section{NON-ISOTOPIC ISH}

Well defined NBT/BCIP sites of hybridisation were seen in cells in all control and patient bone marrow trephine specimens. Background staining was negligible and morphology was well preserved on all occasions. Negative controls did not yield a signal on any occasion. In contrast to both duodenal mucosa ${ }^{13}$ and tonsil (manuscript submitted), in which the distribution of $\mathrm{J}$ chain mRNA expressing cells demonstrated a predictable distribution, marrow J chain mRNA positive cells have an apparently random distribution (fig 1).

Enumeration of the absolute numbers of $\mathrm{J}$ chain mRNA positive cells within each biopsy specimen revealed a similar number of cells per unit length in both control $(17 \cdot 7 \pm 2 \cdot 4$ cells/ $\mathrm{mm})$ and patient $(16 \cdot 5 \pm 2 \cdot 7$ cells $/ \mathrm{mm})$ samples $(\mathrm{p}=\mathrm{NS}$ ) (fig 2).

\section{COMBINED NON-ISOTOPIC ISH AND}

IMMUNOFLUORESCENCE

Monomeric (cytoplasmic IgA positive, J chain mRNA negative) and dimeric (cytoplasmic IgA positive, $\mathrm{J}$ chain mRNA positive) IgA cells were readily distinguished using this technique (fig 3 ).

A greater proportion of IgA plasma cells were $\mathrm{J}$ chain $\mathrm{mRNA}$ positive in patient $(7 \cdot 1 \pm 1 \cdot 45 \%)$ compared with control $(3 \pm 0 \cdot 8 \%)$ trephine biopsy specimens $(p<0.04)$ (fig 4$)$. 


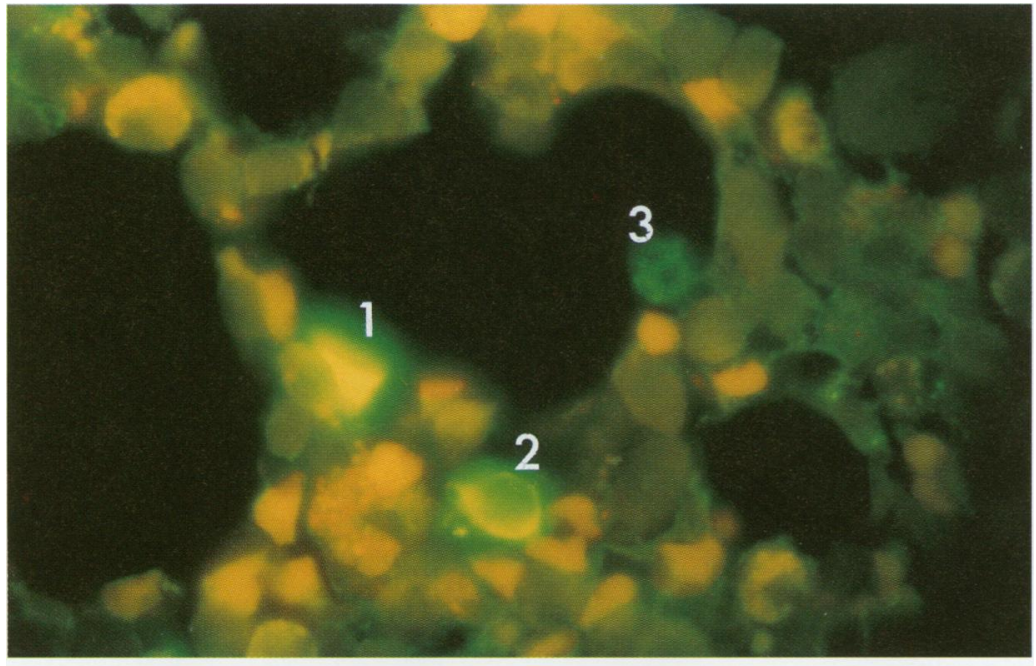

(A)

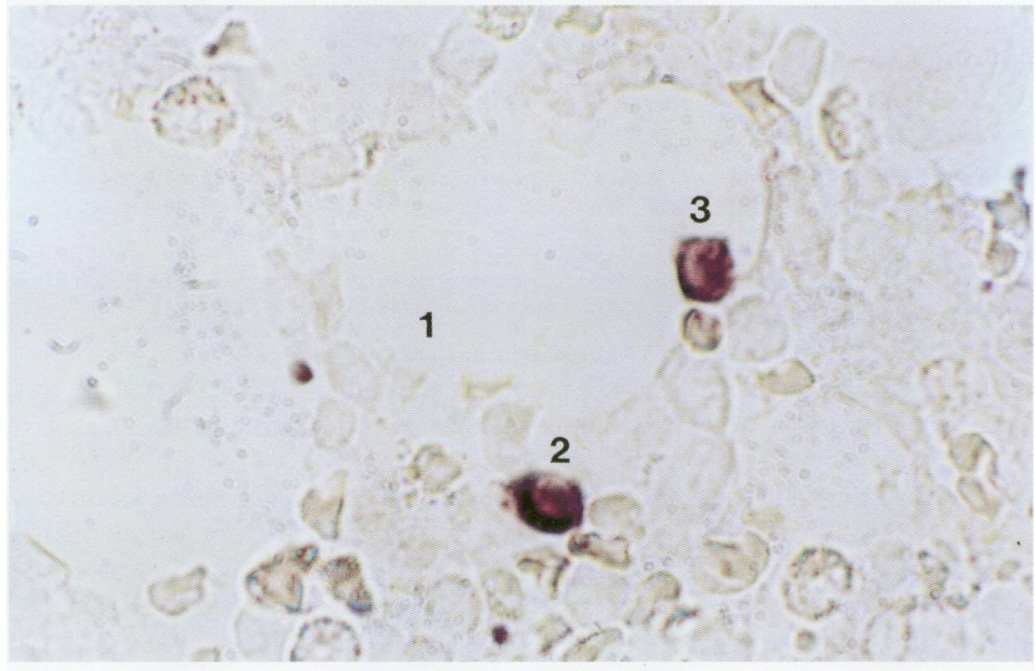

(B)

Figure 3 Combined immunofluorescence for cytoplasmic IgA $(A)$ and non-isotopic ISH for $\mathcal{F}$ chain $m R N A(B)$. Monomeric IgA cells ( (cell 1) IgA positive, $\mathcal{F}$ chain $m R N A$ negative) and dimeric IgA cells ((cells 2 and 3) IgA positive, $\mathcal{F}$ chain $m R N A$ positive) can be clearly identified $(\times 1000)$.

SERUM POLYMERIC IgA

Serum IgA concentrations from the controls and patients studied here have been reported previously. ${ }^{19}$ In the samples from these 14 subjects polymeric IgA represented between 1 and $6 \%$ of serum IgA concentrations. Although the patients generally had higher values of polymeric IgA $(91 \pm 22 \mathrm{mg} / \mathrm{l})$ compared with controls $(77 \pm 24 \mathrm{mg} / \mathrm{l})$, this was not statistically significant.

Furthermore, we could not demonstrate a correlation between serum polymeric IgA and the percentage (or absolute numbers) of J chain mRNA positive IgA plasma cells in bone marrow trephine biopsy specimens. There was no statistical correlation either individually or when the groups were combined.

\section{Discussion}

We have previously described a technique for the simultaneous identification of mRNA bynon-isotopic ISH and cytoplasmic protein by immunofluorescence in paraffin wax embedded and archival tissue. ${ }^{23}$ We have now extended this technique for use on frozen tissue (manu-

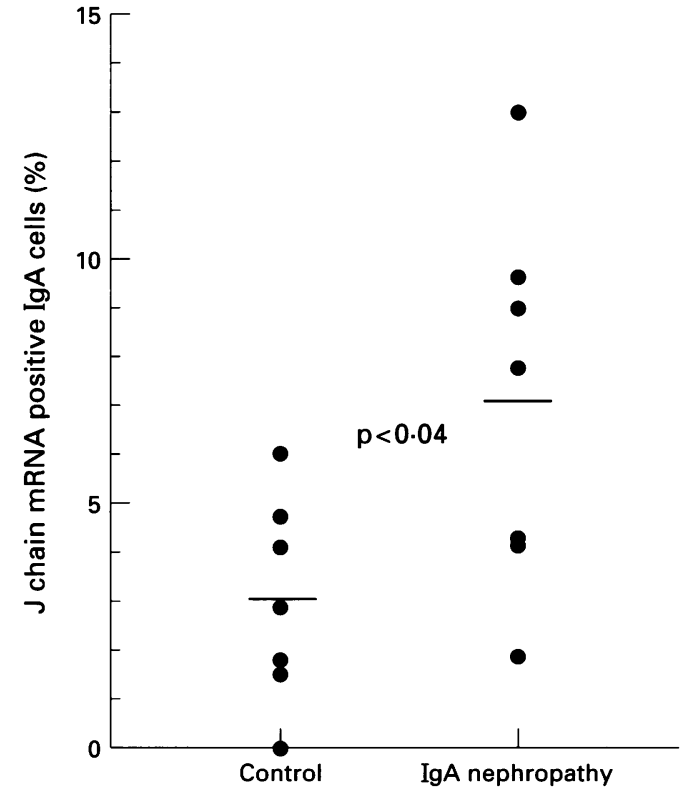

Figure 4 Scatter plot of the percentage of $\mathcal{f}$ chain $m R N A$ positive IgA $B$ cells in bone marrow trephine biopsy specimens from seven patients with confirmed Ig $A$ nephropathy and seven matched controls. - = mean.

script submitted) and on decalcified specimens. ISH on decalcified tissue is hampered by the fact that mRNA tends to degrade during the decalcification process. Our preliminary studies suggested that decalcification with EDTA at neutral $\mathrm{pH}$ gave much better results than decalcification with acid, confirming the previous findings of other authors. ${ }^{27} \mathrm{We}$ also found that non-isotopic ISH on bone marrow trephine biopsy specimens produced a significant amount of background staining, which was only eliminated after the addition of an acetylation step to the specimen pretreatment protocol and incubation of the antidigoxigenin antibody with sheep serum during the detection step. We have found the technique robust and reliable on tissue up to four years old.

This is the first report of the demonstration of J chain mRNA in bone marrow by ISH. We have shown that although absolute numbers of $\mathrm{J}$ chain mRNA positive cells are similar in patients and controls, there is an increase in the proportion of IgA cells which express J chain mRNA in patients. We have recently reported an excess number of IgA and IgA1 cells in the bone marrow biopsy specimens studied here. ${ }^{19}$

Although the expression of $\mathrm{J}$ chain mRNA is not exclusively associated with the production of polymeric IgA in other immunocytes, experimental studies in a Chinese hamster ovary cell expression system (JD Atkin et al, manuscript submitted) suggest that J chain mRNA is essential for the production of dimeric IgA, in contrast to multimeric (hexamer) $\operatorname{IgM} .^{28}$ Transfection experiments in a mouse myeloma cell line, J558L with an $\alpha$ heavy chain, both with and without the $\mathrm{J}$ chain binding terminal cysteine residues support this proposal, (JD Atkin et al, manuscript submitted). Our results therefore suggest a shift towards dimeric IgA1 production in the marrow in $\operatorname{IgA}$ nephropathy. 
We found no correlation between the proportion of dimeric IgA marrow cells and serum polymeric IgA. The reason for this is unclear but may relate to the fact that some serum polymeric IgA exists as aggregated (J chain free) monomers. Any association between dimer producing IgA cells and serum dimeric IgA may therefore be masked by the presence of $\mathrm{J}$ chain free IgA macromolecules. Alternatively, the abnormal concentrations of serum polymeric IgA in IgA nephropathy may derive from another site-for example, tonsils or spleen, or the lack of any association may simply reflect the small numbers of patients studied. Although it would have been preferable to study a larger population, bone marrow biopsy specimens can only be taken from willing volunteers with informed consent. Not unexpectedly, the number of volunteers was small.

Nevertheless, this study provides new information about abnormal dimeric IgA biology in IgA nephropathy. The findings mirror those in the tonsil (manuscript submitted) and are the complete opposite of those in the duodenal lamina propria. IgA is a very $\mathrm{T}$ cell dependent isotype. J chain mRNA expression is orchestrated by $\mathrm{T}$ cell products. ${ }^{28}{ }^{29}$ The abnormal patterns of IgA and J chain mRNA expression in these three tissues may reflect an abnormality of $T$ cell control, perhaps as a result of defective $T$ cell trafficking or innate abnormalities of a $T$ cell population. We recently reported an abnormality of IgA affinity maturation in IgA nephropathy, another $T$ cell dependent function. ${ }^{30}$

Under normal circumstances the mucosal and systemic IgA systems are believed to be related but distinct. ${ }^{31}$ We have now described abnormalities in $\mathrm{J}$ chain mRNA expression in both systems. These findings add to the number of abnormalities of both systems described by others. ${ }^{1214-1820}$ Collectively, these findings raise the possibility that in IgA nephropathy there is an imbalance in the putative mucosa-marrow immune axis, well recognised in mice ${ }^{32}$ but yet to be characterised in man, resulting in an exaggerated overlap between the two systems.

In conclusion, combined non-isotopic ISH and immunofluorescence can be used to detect simultaneously mRNA and cytoplasmic protein, respectively, in decalcified specimens. We have used this method to demonstrate an abnormal shift towards dimeric IgA production within the systemic IgA immune system. This underlines immune abnormalities within the bone marrow in IgA nephropathy and highlights the bone marrow as a possible source of the raised serum concentrations of polymeric IgA and deposited dimeric IgA, which is characteristic of this form of glomerular disease.

SJH is a Wellcome Trust Advanced Training Fellow. Grant $034937 / 91$.

1 D'Amico G. The commonest glomerulonephritis in the world: IgA Nephropathy. $Q \mathcal{F}$ Med 1987;64:709-27.

2 Berger J, Hinylais N. Les depots intercapillaires d'IgA-IgG. f Urol Nephrol (Paris) 1968;74:694-5.

F Urol Nephrol (Paris) 1968;74:694-5. A1 in IgA nephropathy. $N$ Engl $f$ Med $1981 ; 305: 1159-60$. 4 Bene M-C, Faure G, Duheille J. IgA nephropathy: charBene M-C, Faure G, Duheille J. IgA nephropathy: char-
acterization of the polymeric nature of mesangial deposits by in vitro binding of free secretory component. Clin $\operatorname{Exp}$ Immunol 1982;47:527-34.

5 Tomino Y, Sakai H, Miura M, Endoh M, Nomoto Y. Detection of polymeric IgA in glomeruli from patients with IgA nephropathy. Clin Exp Immunol 1982;49:419-25.

6 Monteiro RC Halbwachs-Mecarelli I Roque-Barreir MC No RC, Halbwachs-Mecarelli L, Roque-Barreir mesangial IgA in IgA nephropathy. Kidney Int 1985;28: mesangial

7 Harper SJ, Feehally J. The pathogenic role of IgA polymers in IgA nephropathy. Nephron 1993;65:337-45.

8 Jones CL, Powell HR, Kincaid-Smith P, Roberton DM. Polymeric IgA and immune complex concentrations in IgA related renal disease. Kidney Int 1990;38:323-31.

9 Emancipator SN, Lamm ME. IgA Nephropathy: Pathogenesis of the most common form of glomerulonephritis. Lab Invest 1989;60:168-83.

10 Coppo $R$. The pathogenetic potential of environmental antigens in $\operatorname{IgA}$ nephropathy. Am 7 Kid Dis 1988;10: $420-4$.

11 Feehally J. Immune mechanisms in glomerular IgA deposition. Nephrol Dial Transplant 1988;3:361-78.

12 Hene RJ, Schuurman H-J, Kater L. Immunoglobulin A subclass-containing plasma cells in the jejunum in primary IgA nephropathy and in Henoch-Schönlein purpura. $\mathrm{Ne}$ IgA nephropathy and

13 Harper SJ, Pringle JH, Wicks ACB, Hattersley J, Layward $\mathrm{L}$, Allen AC, et al. Expression of $\mathrm{J}$ chain mRNA in duodenal IgA plasma cells in IgA nephropathy. Kidney In 1994;45:836-44.

14 Egido J, Blasco R, Lozano L, Sancho J, Garcia-Hoyo R. Immunological abnormalities in the tonsils of patients with IgA nephropathy: inversion in the ratio of IgA:IgG bearing lymphocytes and increased polymeric IgA synthesis. Clin Exp Immunol 1984;57:101-6.

15 Bene M-C, Faure G, Hurault De Ligny B, Kessler M, Duheille J. Immunoglobulin A nephropathy: quantitative immunohistomorphometry of the tonsillar plasma cells evidences an inversion of the immunoglobulin A versus immunoglobulin G secreting cell balance. $\mathcal{f}$ Clin Invest immunoglobulin

16 Nagy J, Brandtzaeg P. Tonsillar distribution of IgA and IgG immunocytes and production of IgA subclasses and chain in tonsillitis vary with the presence or absence of IgA nephropathy. Scand f Immunol 1988;27:393-9.

17 Bene M-C, De Ligny BH, Kessler M, Faure GC. Confirmation of tonsillar anomalies in IgA nephropathy: A multicenter study. Nephron 1991;58:425-8.

18 van den Wall Bake AWL, Daha MR, Radl J, Haaijman JJ, Van der Ark A, Valentijn RM, van Es LA. The bone marrow as production site of the IgA deposited in the kidneys of patients with IgA nephropathy. Clin Exp Imkidneys of patients with

19 Harper SJ, Allen AC, Layward L, Hattersley J, Veitch PS, Feehally J. Increased immunoglobulin A and immunoglobulin A1 cells in bone marrow trephine biopsy specimens in immunoglobulin A nephropathy. $A m \mathcal{F}$ Kid Dis 1994;24:888-92.

20 van den Wall Bake AWL, Daha MR, Evers-Schouten J, van Es LA. Serum IgA and the production of IgA by periphera blood and bone marrow lymphocytes in patients with primary IgA nephropathy: evidence for the bone marrow as the source of mesangial IgA. Am f Kid Dis 1988;12: 410-14.

21 Max EE, Korsmeyer SJ. Human J chain gene. Structure and expression in B lymphoid cells. $\mathcal{F}$ Exp Med 1985;161: $832-49$.

22 Pringle JH, Ruprai AK, Primrose L, Keyte J, Potter L, Close $P$, Lauder I. In situ hybridization of immunoglobulin light chain mRNA in paraffin sections using biotinylated or hapten-labelled oligonucleotide probes. F Pathol 1990 162:197-207.

23 Harper SJ, Pringle JH, Gillies A, Allen AC, Layward L, Feehally J, Lauder I. Simultaneous in situ hybridisation of native mRNA and immunoglobulin detection by conventional immunofluorescence in paraffin wax embedded sections. F Clin Pathol 1992;45:114-19.

24 Shorrock K, Roberts PA, Pringle JH, Lauder I. Demonstration of insulin and glucagon mRNA in routinely fixed and processed pancreatic tissue by in situ hybridization. $\mathcal{F}$ Pathol 1991;165:105-10.

25 Jones PH, Harper SJ, Watts FM. Stem cell patterning and fate in human epidermis. Cell 1995;80:83-93. 26 Layward L, Finnemore A-M, Allen AC, Harper SJ, Feehally
J. Systemic and mucosal IgA responses to systemic antigen challenge in IgA nephropathy. Clin Immunol Immunopatho challenge in IgA

27 Akhtar N, Ruprai A, Pringle JH, Lauder I, Durrant STS In situ hybridization detection of light chain mRNA in routine bone marrow trephines from patients with suspected myeloma. Br $\mathcal{F}$ Haematol 1989;73:296-301.

28 Brewer JW, Randall TD, Parkhouse RME, Corley RB. IgA hexamers? Immunol Today; 1994;15:165-8.

29 Takayasu H, Brooks KH. IL-2 and IL- 5 both induce US and $J$ chain mRNA in a clonal B cell line, but differ in their cell-cycle dependency for optimal signaling. Cell Immunol 1991;136:472-85.

30 Layward L, Allen AC, Hattersley J, Harper SJ, Feehally J. Low antibody affinity restricted to the IgA isotype in IgA nephropathy. Clin Exp Immunol 1994;95:35-41.

31 Brandtzaeg P. Overview of the mucosal immune system. Curr Top Microbiol Immunol 1989;146:13-25.

32 Alley CD, Kiyono H, McGhee JR. Murine bone marrow IgA responses to orally administered sheep erythrocytes. f Immunol 1986;136:4414-19. 